\title{
Discrete Event Simulation and Data Envelopment Analysis Models for Selecting the Best Resource Allocation Alternative at an Emergency Department's Green Zone
}

(Simulasi Peristiwa Diskret dan Analisis Penyampulan Data untuk Pemilihan Alternatif

Pengagihan Sumber yang Terbaik di Zon Hijau Jabatan Kecemasan)

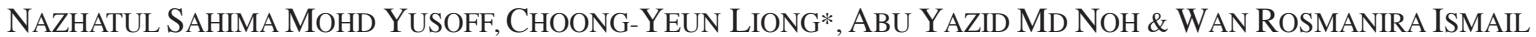

\begin{abstract}
The Green Zone of Emergency Department Hospital Universiti Sains Malaysia (EDHUSM) which provides treatment for non-critical cases contributes partly to the hustle and bustle in the emergency department. The imbalance of doctors and nurses with the patient ratio which forms the resources' bottleneck further results to the long patients'waiting time especially after the office hours and during weekends and public holidays. Collectively, this disproportion and bottlenecks roots up the current problem faced by Green Zone EDHUSM which constantly fails to achieve the KPIs set by the hospital. Henceforth, this study focuses on the best resource allocation of doctors and nurses for shifts during the weekdays and for shifts during weekends and public holidays. The hybrid method of Discrete Event Simulation, and Data Envelopment Analysis models such as BCC-input oriented and Super-Efficiency, were deployed to obtain the best resource allocation for the two groups of shift. The method produced a series of resources allocation alternatives for doctors and nurses with a total of 64 alternatives for weekdays and 729 alternatives for weekends and public holidays. The results show that the best allocation for doctors and nurses during weekdays are three doctors and three nurses serving for every shift, while during weekends and public holidays, a combination of four doctors and four nurses for every shift are the best. The proposed combinations have reduced the average waiting time, optimized the utilization of doctors and nurses, and managed to increase the number of patients served during weekdays, weekends and public holidays.
\end{abstract}

Keywords: BCC model; data envelopment analysis; discrete event simulation; efficiency scores; simulation; super efficiency model

\section{ABSTRAK}

Zon Hijau Jabatan Kecemasan Hospital Universiti Sains Malaysia (JKHUSM) yang memberikan rawatan untuk kes yang tidak kritikal merupakan antara penyumbang kepada kesibukan dan kesesakan di JKHUSM. Ketakseimbangan antara jumlah doktor dan jururawat dengan nisbah pesakit mengakibatkan kesendatan sumber yang menyebabkan purata masa menung gu pesakit yang panjang terutamanya selepas waktu pejabat bagi hari bekerja dan pada cuti hujung minggu dan kelepasan am. Secara kolektif, ketakseimbangan dan kesendatan ini merupakan faktor utama kepada masalah yang dialami di Zon Hijau JKHUSM dan seterusnya gagal mencapai Penunjuk Prestasi Utama jabatan yang ditetapkan oleh hospital. Oleh itu, kajian ini memberi tumpuan kepada menentukan pengagihan sumber yang terbaik dalam memperuntukkan jumlah doktor dan jururawat yang bekerja mengikut syif untuk kelompok hari biasa dan kelompok hari cuti hujung minggu dan hari kelepasan am. Kaedah hibrid Simulasi Peristiwa Diskret dengan model BCC-berorentasikan input dan model Kecekapan Super yang terdapat dalam kaedah Analisis Penyampulan Data telah digunakan bagi mendapatkan alternatif pengagihan sumber yang terbaik bagi kedua-dua kelompok syif tersebut. Sejumlah 64 alternatif kombinasi untuk doktor dan jururawat untuk setiap syif telah dicadangkan bagi kelompok hari bekerja, dan 729 alternatif bagi kelompok cuti hujung minggu dan kelepasan am. Keputusan menunjukkan jumlah doktor dan jururawat yang sepatutnya bertugas bagi kelompok hari bekerja adalah seramai tiga orang doktor dan tiga orang jururawat untuk setiap syif, manakala untuk kelompok cuti hujung minggu dan kelepasan am pula, gabungan empat orang doktor dan empat orang jururawat bertugas bagi setiap syif adalah terbaik. Gabungan yang dicadangkan telah mengurangkan purata masa menunggu pesakit, mengoptimumkan penggunaan sumber dan berjaya meningkatkan bilangan pesakit yang dirawat pada hari biasa serta pada hari cuti hujung minggu dan kelepasan am.

Kata kunci: Analisis penyampulan data; model BCC; model kecekapan super; skor kecekapan; simulasi; simulasi peristiwa diskret

\section{INTRODUCTION}

Green Zones in an Emergency Department (ED) plays the role as an outpatient clinic of a hospital. This zone is entirely dedicated to attend to patients with non-critical conditions and injuries (Komashie \& Mousavi 2005). Although the Green Zone department caters merely 
non-critical cases, many patients' experiences a lengthy waiting period before receiving treatment as well as endure the overcrowded situation at the ED. Due to this problem, some patients' even leaves without being treated especially during peak hours. Therefore, the concern of any ED in the world is to provide speedy treatment while reducing patients' waiting time and length of stay (Eduardo et al. 2012). Besides that, other issue that plunges at the ED are the insufficient resources allocation such as medical officers and beds (Norazura et al. 2014). As a result, many previous researchers have conducted research in EDs using either single method or hybrid methods. While most of the researchers used the Discrete Event Simulation (DES) method as it is the popular single tool to resolve problems in the ED (Blasak et al. 2003; Chahal \& Eldabi 2008; Gunal \& Pidd 2010), Al-Shayea (2011) chose the Data Envelopment Analysis (DEA) method. Moreover, in recent years many researchers have introduced hybrid methods in resolving problems in ED by integrating DES with System Dynamic Simulation (Brailsford et al. 2010; Chahal \& Eldabi 2010; Norazura et al. 2012) and integrating DES with DEA (Al-Refaie et al. 2014; Weng et al. 2011).

Similarly, the Green Zone in Emergency Department of Hospital Universiti Sains Malaysia (EDHUSM) also experiences the same dilemma as it is one of the busiest hospitals in the capital city of Kelantan, Malaysia. The, lengthy patients' waiting time and over-crowdedness especially after weekdays' office hours, weekends and public holidays are the key problem befalling EDHUSM's Green Zone. As a result, the department failed to achieve its KPI on waiting period that is set to be below $120 \mathrm{~min}$ especially during weekends and public holidays.

Based on the interviews and surveys conducted, the rescheduling of the current timetable of doctors and nurses serving in EDHUSM could not be done due to the shortage and insufficient resources especially during peak hours, weekends and public holidays. Hence, the utilization of doctors and nurses are high and almost fully utilized. Conclusively, this situation creates exhaustion for the doctors and nurses where there are times that they are unable to even take a proper break. Thus, it is crucial for this issues to be rectified since doctors are the key resources and the authorised personnel to make healthcare decisions for patients, while the nurses supports the doctors in many medical processes. According to Mohd et al. (2016), a good utilization of resources in the service sector should be in the range of $70 \%$ to $80 \%$. Therefore, the key challenge for the management of EDHUSM is to estimate the right number of doctors and nurses that is required to be allocated for every shift in the Green Zone especially during weekdays, weekends and public holidays. Hence, proper allocation of doctors and nurses is necessary by either adding or rescheduling staffs in order to ensure that there is an improvement in the utilization of doctors and nurses. Besides that, patients must be treated within the permitted waiting time which as a result would enable EDHUSM's Green Zone to achieve the KPI set. Therefore, this study will focus on improving and reducing the average patients waiting time in order to meet the EDHUSM Green Zone's KPI, propose the best combination of allocation of doctors and nurses for every shift, as well as reduce and improve doctors' and nurses' utilisation during weekdays, weekends and public holidays by using DES, BCC input-oriented model and Super Efficiency model in DEA method.

\section{SYSTEM DESCRIPTION}

EDHUSM's Green Zone operates $24 \mathrm{~h}$ a day and 7 days a week throughout the year. In ensuring smooth operation, the work shifts in the Green Zone are slotted into three categories namely morning, evening and night shifts. The morning shift begins at 0700 to $1400(7 \mathrm{~h})$ continued by the evening shift for another $7 \mathrm{~h}$ from 1400 to 2100 . The night shifts are extended for $10 \mathrm{~h}$ beginning at 2100 and end the next day 0800. The standard operating hours of HUSM Kelantan is from Sunday to Thursday (weekdays) while Fridays' and Saturdays' are considered as weekends.

The process flow for the Green Zone patients begins with patients' arrival by walk-in to EDHUSM. Upon their arrival, the patients will proceed to the registration counter first to register. Thereafter, the patient will be triaged by a nurse at the triage counter. Upon a triage procedure, the patients will proceed to the waiting area in order to receive consultation from the doctors. The utilization of consultation rooms are at its minimal as only two consultation rooms are utilized even though five consultation rooms exist in the ED. This underutilization are due to shortages of resources in the ED with only two doctors and two nurses works in a shift during weekdays, weekends and public holidays.

Henceforth, the doctors will decide if the patients require further tests, such as clinically laboratory tests, $\mathrm{X}$-rays test, counselling session and Plaster of paris (POP) treatment. Patients normally wait between 30 and $60 \mathrm{~min}$ for the results. The second consultation from the doctor can be obtained shortly after receiving the test results. The results obtained will be reviewed by the doctors and the decisions are made upon the results either to discharge the patient or admit to other zones or hospital wards. From $24 \mathrm{~h}$ monthly data collection, a total of 19 days belongs to the weekday's group while another 10 days belong to the weekend's group which includes 2 days public holiday for the Chinese New Year celebration in February. A total number of 1500 patients visited the Green Zone during weekdays with an average of 79 patients per day, while 1203 patients visited Green Zone during weekends and public holidays with an average of 120 patients per day.

\section{DISCRETE EVENT SIMULATION (DES)}

Discrete Event Simulation (DES) is one of the techniques that can save time, cost and be proven to be the most powerful tool for decision makers to study, analyze and 
evaluate any situations from simple to complex processes (Kelton et al. 2015). Development of DES models is the first phase of this research and starts by focusing on a preliminary study that requires sufficient comprehension of the problems under study identified through interviews with the administrators and staff; regarding the process flows of the department. Then, several observations will be made to understand the patient flow in the Green Zone EDHUSM. After that, data collection is conducted. For this study, the data were collected in one month for $24 \mathrm{~h}$. Data collection for Green Zone involves patient's arrival time, doctor service time, patient discharge time, number of patients in, number of patients out and processing time for each test.

The Green Zone EDHUSM model is developed using Arena 14.0 to visualize the actual operation. A total of 64 combination schedules for doctor and nurse have been proposed for weekdays while 729 combination schedules were proposed for weekends and public holidays. The set of combination are different for both group because it depends on the requirement of the hospital. Each combination schedules are treated as DMU, starting with $\mathrm{DMU}_{0}$ as the current schedule and from DMU1 to DMU63 as a proposed schedule for doctors and nurses during weekdays. While, for weekends and public holidays, it starts with DMU as the current schedule and from DMU1 to DMU728 as a proposed schedule for doctors and nurses. The simulation results from DES models will show the average waiting time and the utilization of doctors and nurses for all combination schedules that represent current scenario and proposed scenarios for both groups. This variable will be an input and output that is needed for DEA method in second phase of this research.

\section{DEA-BCC INPUT ORIENTED MODEL AND DEA-SUPER EFFICIENCY MODEL}

Data Envelopment Analysis (DEA) is a linear programming method utilized to measure the relative efficiency of homogeneous decision making units (DMUs) (Al-Shayea 2011; Chun \& Okudan 2009; Ertay et al. 2006; Gunal \& Pidd 2010; Wan et al. 2016). DEA-BCC input-oriented were applied in the second phase of this research in order to evaluate the process efficiency in EDHUSM's Green Zone. In brief, the BCC model which is named after Banker et al. (1984), is assuming variable returns to scale (VRS), where any changes in the inputs or outputs do not produce a proportional change in the outputs or inputs, respectively (Ruzanita et al. 2014). There are two model orientations in the DEA namely input-oriented and outputoriented whereby the input-oriented objective is to reach a minimum level of input to the given output while the output oriented objective is to reach a maximum level of output to the given input. Since the performance of Green Zone EDHUSM services are not always linear, most healthcare facilities aims to achieve a higher patients' service level by using fewer resources for instance balancing the number of doctors and nurses (Wan et al. 2016). Here is the BCC input-oriented model:

$$
\begin{array}{ll}
\operatorname{Max} \theta_{0}= & \sum_{j=1}^{m} u_{j} y_{j o}+u_{o} \\
\text { s.t. } & \\
& \sum_{i=1}^{s} v_{i} x_{i o}=1 \\
& \sum_{j=1}^{m} u_{j} y_{j k}-\sum_{i=1}^{s} v_{i} x_{i k}+u_{o} \leq 0 \\
& v_{i} \geq 0, u_{j} \geq 0, u_{o} \text { is free in sign }
\end{array}
$$

where $\theta_{0}$ is the efficiency score for $\mathrm{DMU}_{0}$ that is evaluated; $x_{i 0}$ is the vector of input $\mathrm{DMU}_{0}, y_{j 0}$ is the vector of output at $\mathrm{DMU}_{j} ; x_{i k}$ is the actual amount of input $i$ used by $\mathrm{DMU}_{k}$; $y_{j k}$ is the actual amount of output $\mathrm{j}$ produced by $\mathrm{DMU}_{k}$; and $u$ and $v$ are the weights attached to inputs and outputs. If $\mathrm{DMU}_{0}$ is efficient, $\theta_{0}$ equals 1 . Otherwise, $\theta_{0}$ is less than 1 (Cooper et al. 2007; Ruzanita et al. 2014; Wan et al. 2016; Weng et al. 2011). At times, more than one DMUs resultants to be efficient. Due to that, Super EfficiencyBCC technique which was introduced by Seiford and Zhu (1999) is used to overcome such problems by ranking the efficient DMUs (Ruzanita et al. 2014). This technique modifies the model above by eliminating constrains related to DMUs that are under evaluation. The Super Efficiency-BCC model is as follows:

$$
\begin{array}{ll}
\varphi_{o}= & \sum_{j=1}^{m} u_{j} y_{j o}+u_{o} \\
\text { s.t. } & \\
& \sum_{i=1}^{s} v_{i} x_{i o}=1 \\
& \sum_{j=1}^{m} u_{j} y_{j k}-\sum_{i=1}^{s} v_{i} x_{i k}+u_{o} \leq 0 \\
& v_{i} \geq 0, u_{j} \geq 0, u_{o} \text { is free in sign }
\end{array}
$$

The Super-Efficiency score should be obtained from

$$
\left(\frac{1}{\varphi_{o}}>1\right)
$$

The highest Super-Efficiency score for both categories are selected as the best DMU to be applied by EDHUSM's Green Zone.

\section{RESULTS AND DISCUSSION}

A total of 64 simulation models and resource allocation alternatives (DMUs) for weekdays and 729 simulation models and DMUs for weekends and public holidays were modelled to represent the current scenario and proposed combination of doctors and nurses for each group. These models run $24 \mathrm{~h}$ for 30 replicated times. Basically, the value of the average waiting time, average utilization of doctors, average utilization of nurses and number of served patients are obtained from the DES model results. While the BCC efficiency score and Super Efficiency score are obtained from the DEA models results. Relatively, the number of doctors, number of nurses and the average waiting time are set as inputs because smaller values are preferred while the average utilization of doctors, average utilization of nurses and numbers of served patients are set as outputs since larger values are preferred. Based 
on Super Efficiency score illustrated in Table 1, DMU63 ranked the highest for weekdays. It shows that for weekdays the best schedules are 3 doctors and 3 nurses on duty for each shift. This means that a doctor and a nurse are required to be added to the current schedule for weekdays. Therefore, as illustrated in Table 2, Super Efficiency ranks DMU728 as the highest for weekends and public holidays. Meanwhile, DMU728 suggests adding on two doctors and two nurses for every shift. Thus, four doctors and nurses are required for every shift in order to reduce the congestion in Green Zones during weekends and public holidays and to further achieve the Green Zone's KPI. This is due to all outpatient departments and healthcare clinics are closed during weekends and public holidays.

Table 3 summarizes the comparison of results for both groups. The comparison between the highest ranks DMU728 and the current scenario $\mathrm{DMU}_{0}$ for weekends and public holidays shows that the average patients' waiting time prior to obtaining treatment in Green Zone indicates

TABLE 1. Proposed resource alternatives and results of BCC and super efficiency models for weekdays

\begin{tabular}{|c|c|c|c|c|c|c|c|c|c|}
\hline DMUs & $\begin{array}{l}\text { Number } \\
\text { of doctor }\end{array}$ & $\begin{array}{l}\text { Number } \\
\text { of nurse }\end{array}$ & $\begin{array}{l}\text { Average } \\
\text { waiting } \\
\text { time }\end{array}$ & $\begin{array}{c}\text { Average } \\
\text { utilization of } \\
\text { doctor }\end{array}$ & $\begin{array}{l}\text { Average } \\
\text { utilization } \\
\text { of nurse }\end{array}$ & $\begin{array}{l}\text { Number } \\
\text { of served } \\
\text { patients }\end{array}$ & $\begin{array}{c}\text { BCC } \\
\text { efficiency } \\
\text { score }\end{array}$ & $\begin{array}{c}\text { Super } \\
\text { efficiency } \\
\text { score }\end{array}$ & $\begin{array}{c}\text { Super } \\
\text { efficiency } \\
\text { rank }\end{array}$ \\
\hline 0 & $6(2,2,2)$ & $6(2,2,2)$ & 78.75 & 85 & 95 & 76 & 1 & 1.150257 & 2 \\
\hline 1 & $6(2,2,2)$ & $7(2,2,3)$ & 89.27 & 87 & 83 & 78 & 1 & 1.011628 & 7 \\
\hline 2 & $6(2,2,2)$ & $7(2,3,2)$ & 82.6 & 86 & 84 & 78 & 1 & 1.001203 & 13 \\
\hline 3 & $6(2,2,2)$ & $8(2,3,3)$ & 91.08 & 87 & 74 & 79 & 1 & 1.006061 & 10 \\
\hline 4 & $6(2,2,2)$ & $7(3,2,2)$ & 61.21 & 84 & 84 & 78 & 1 & 1.057745 & 4 \\
\hline 5 & $6(2,2,2)$ & $8(3,2,3)$ & 67.16 & 85 & 73 & 79 & 1 & 1.008131 & 8 \\
\hline 6 & $6(2,2,2)$ & $8(3,3,2)$ & 77.61 & 86 & 75 & 79 & 1 & 1.001777 & 12 \\
\hline 7 & $6(2,2,2)$ & $9(3,3,3)$ & 83.97 & 85 & 63 & 79 & 1 & 1 & 14 \\
\hline 8 & $7(2,2,3)$ & $6(2,2,2)$ & 86.68 & 74 & 95 & 77 & 1 & 1.005848 & 11 \\
\hline 9 & $7(2,2,3)$ & $7(2,2,3)$ & 59.25 & 75 & 83 & 79 & 0.952551 & - & - \\
\hline 10 & $7(2,2,3)$ & $7(2,3,2)$ & 84.37 & 75 & 84 & 78 & 0.892978 & - & - \\
\hline 11 & $7(2,2,3)$ & $8(2,3,3)$ & 68.06 & 76 & 74 & 79 & 0.882048 & - & - \\
\hline 12 & $7(2,2,3)$ & $7(3,2,2)$ & 65.59 & 74 & 53 & 78 & 0.92803 & - & - \\
\hline 13 & $7(2,2,3)$ & $8(3,2,3)$ & 47.47 & 75 & 43 & 79 & 0.945955 & - & - \\
\hline 14 & $7(2,2,3)$ & $8(3,3,2)$ & 78.68 & 76 & 75 & 79 & 0.871324 & - & - \\
\hline 15 & $7(2,2,3)$ & $9(3,3,3)$ & 64.36 & 76 & 64 & 79 & 0.887302 & - & - \\
\hline 16 & $7(2,3,2)$ & $6(2,2,2)$ & 86.2 & 76 & 94 & 77 & 1 & 1 & 15 \\
\hline 17 & $7(2,3,2)$ & $7(2,2,3)$ & 95.47 & 78 & 83 & 78 & 0.879699 & - & - \\
\hline 18 & $7(2,3,2)$ & $7(2,3,2)$ & 36.85 & 75 & 83 & 79 & 1 & 1.051016 & 5 \\
\hline 19 & $7(2,3,2)$ & $8(2,3,3)$ & 40.24 & 67 & 83 & 79 & 0.984859 & - & - \\
\hline 20 & $7(2,3,2)$ & $7(3,2,2)$ & 85.07 & 66 & 86 & 78 & 0.891722 & - & - \\
\hline 21 & $7(2,3,2)$ & $8(3,2,3)$ & 62.38 & 66 & 74 & 79 & 0.897298 & - & - \\
\hline 22 & $7(2,3,2)$ & $8(3,3,2)$ & 37.04 & 66 & 73 & 79 & 0.983253 & - & - \\
\hline 23 & $7(2,3,2)$ & $9(3,3,3)$ & 28.37 & 66 & 64 & 79 & 1 & 1.052527 & 4 \\
\hline 24 & $8(2,3,3)$ & $6(2,2,2)$ & 94.17 & 65 & 94 & 77 & 1 & 1 & 16 \\
\hline 25 & $8(2,3,3)$ & $7(2,2,3)$ & 69.33 & 66 & 83 & 79 & 0.905366 & - & - \\
\hline 26 & $8(2,3,3)$ & $7(2,3,2)$ & 40.25 & 67 & 83 & 79 & 0.989177 & - & - \\
\hline 27 & $8(2,3,3)$ & $8(2,3,3)$ & 29.76 & 67 & 74 & 79 & 0.935029 & - & - \\
\hline 28 & $8(2,3,3)$ & $7(3,2,2)$ & 85.07 & 66 & 75 & 78 & 0.869889 & - & - \\
\hline 29 & $8(2,3,3)$ & $8(3,2,3)$ & 62.38 & 66 & 74 & 79 & 0.841805 & - & - \\
\hline 30 & $8(2,3,3)$ & $8(3,3,2)$ & 37.04 & 66 & 73 & 79 & 0.87881 & - & - \\
\hline
\end{tabular}


Continue TABLE 1.

\begin{tabular}{|c|c|c|c|c|c|c|c|c|c|}
\hline DMUs & $\begin{array}{l}\text { Number } \\
\text { of doctor }\end{array}$ & $\begin{array}{l}\text { Number } \\
\text { of nurse }\end{array}$ & $\begin{array}{l}\text { Average } \\
\text { waiting } \\
\text { time }\end{array}$ & $\begin{array}{c}\text { Average } \\
\text { utilization of } \\
\text { doctor }\end{array}$ & $\begin{array}{c}\text { Average } \\
\text { utilization of } \\
\text { nurse }\end{array}$ & $\begin{array}{l}\text { Number } \\
\text { of served } \\
\text { patients }\end{array}$ & $\begin{array}{c}\text { BCC } \\
\text { efficiency } \\
\text { score }\end{array}$ & $\begin{array}{l}\text { Super } \\
\text { efficiency } \\
\text { score }\end{array}$ & $\begin{array}{c}\text { Super } \\
\text { efficiency } \\
\text { rank }\end{array}$ \\
\hline 31 & $8(2,3,3)$ & $9(3,3,3)$ & 28.37 & 66 & 64 & 79 & 0.920461 & - & - \\
\hline 32 & $7(3,2,2)$ & $6(2,2,2)$ & 68.11 & 76 & 94 & 77 & 1 & 1.048195 & 6 \\
\hline 33 & $7(3,2,2)$ & $7(2,2,3)$ & 77.85 & 77 & 82 & 78 & 0.904843 & - & - \\
\hline 34 & $7(3,2,2)$ & $7(2,3,2)$ & 78.71 & 77 & 83 & 79 & 0.91484 & - & - \\
\hline 35 & $7(3,2,2)$ & $8(2,3,3)$ & 87.03 & 79 & 74 & 79 & 0.871324 & - & - \\
\hline 36 & $7(3,2,2)$ & $7(3,2,2)$ & 42.14 & 75 & 83 & 78 & 0.98423 & - & - \\
\hline 37 & $7(3,2,2)$ & $8(3,2,3)$ & 46.68 & 75 & 72 & 79 & 0.948681 & - & - \\
\hline 38 & $7(3,2,2)$ & $8(3,3,2)$ & 45.1 & 77 & 76 & 79 & 0.961133 & - & - \\
\hline 39 & $7(3,2,2)$ & $9(3,3,3)$ & 48.53 & 76 & 64 & 79 & 0.935783 & - & - \\
\hline 40 & $8(3,2,3)$ & $6(2,2,2)$ & 76.5 & 66 & 94 & 77 & 1 & 1 & 17 \\
\hline 41 & $8(3,2,3)$ & $7(2,2,3)$ & 53.29 & 67 & 82 & 79 & 0.949752 & - & - \\
\hline 42 & $8(3,2,3)$ & $7(2,3,2)$ & 79.8 & 68 & 85 & 79 & 0.883525 & - & - \\
\hline 43 & $8(3,2,3)$ & $8(2,3,3)$ & 65.24 & 67 & 73 & 79 & 0.837322 & - & - \\
\hline 44 & $8(3,2,3)$ & $7(3,2,2)$ & 47.22 & 66 & 83 & 78 & 0.961021 & - & - \\
\hline 45 & $8(3,2,3)$ & $8(3,2,3)$ & 30.39 & 67 & 74 & 79 & 0.931769 & - & - \\
\hline 46 & $8(3,2,3)$ & $8(3,3,2)$ & 45.59 & 67 & 74 & 79 & 0.869122 & - & - \\
\hline 47 & $8(3,2,3)$ & $9(3,3,3)$ & 34.18 & 67 & 64 & 79 & 0.892127 & - & - \\
\hline 48 & $8(3,3,2)$ & $6(2,2,2)$ & 79.26 & 68 & 93 & 77 & 1 & 1 & 18 \\
\hline 49 & $8(3,3,2)$ & $7(2,2,3)$ & 92.94 & 70 & 83 & 78 & 0.869889 & - & - \\
\hline 50 & $8(3,3,2)$ & $7(2,3,2)$ & 39.23 & 66 & 82 & 79 & 0.992399 & - & - \\
\hline 51 & $8(3,3,2)$ & $8(2,3,3)$ & 41.52 & 65 & 73 & 79 & 0.877711 & - & - \\
\hline 52 & $8(3,3,2)$ & $7(3,2,2)$ & 46.4 & 66 & 83 & 78 & 0.963992 & - & - \\
\hline 53 & $8(3,3,2)$ & $8(3,2,3)$ & 51.71 & 67 & 73 & 79 & 0.858962 & - & - \\
\hline 54 & $8(3,3,2)$ & $8(3,3,2)$ & 18.06 & 65 & 72 & 79 & 1 & 1.093577 & 3 \\
\hline 55 & $8(3,3,2)$ & $9(3,3,3)$ & 17.84 & 65 & 64 & 79 & 1 & 1.00640 & 9 \\
\hline 56 & $9(3,3,3)$ & $6(2,2,2)$ & 89.41 & 57 & 94 & 77 & 1 & 1 & 19 \\
\hline 57 & $9(3,3,3)$ & $7(2,2,3)$ & 64.83 & 58 & 82 & 79 & 0.917394 & - & - \\
\hline 58 & $9(3,3,3)$ & $7(2,3,2)$ & 42.95 & 58 & 82 & 79 & 0.980747 & - & - \\
\hline 59 & $9(3,3,3)$ & $8(2,3,3)$ & 32.61 & 58 & 73 & 79 & 0.920461 & - & - \\
\hline 60 & $9(3,3,3)$ & $7(3,2,2)$ & 50.74 & 57 & 83 & 78 & 0.948472 & - & - \\
\hline 61 & $9(3,3,3)$ & $8(3,2,3)$ & 36.4 & 58 & 73 & 79 & 0.901778 & - & - \\
\hline 62 & $9(3,3,3)$ & $8(3,3,2)$ & 19.61 & 58 & 72 & 79 & 0.990879 & - & - \\
\hline 63 & $9(3,3,3)$ & $9(3,3,3)$ & 12.8 & 59 & 65 & 79 & 1 & 1.395898 & 1 \\
\hline
\end{tabular}

**Note: (a/b/c) is (morning shift/evening shift/night shift)

an obvious reduction from 234.07 to $17.78 \mathrm{~min}$. Besides that, the numbers of served patients also increased from 96 to 122 people. Furthermore, the addition of two doctors and two nurses also reduces the high utilization of doctors and nurses from $96 \%$ to $62 \%$ and $100 \%$ to $68 \%$, respectively. As a result, the doctors and nurses are not overburdened and are able to enjoy their short break compared to the current situation.

In contrast, DMU63 is ranked as the best allocation of doctors and nurses for weekdays. The average waiting time reduced from 78.75 to $12.80 \mathrm{~min}$ and the utilization of doctors and nurses also reduced from $85 \%$ to $59 \%$ and $95 \%$ to $65 \%$, respectively. Moreover, the number of patients' served also increased from 76 to 79 people. These results help to improvise the services during weekdays especially on overcrowded situations which occur after office hours. However, the management of EDHUSM can maintain the current schedule $\mathrm{DMU}_{0}$ which is the second best rank for weekdays, rather than incur additional cost of hiring additional staffs, as the average 
TABLE 2. Proposed resource alternatives and results of BCC and super efficiency models for weekends and public holidays

\begin{tabular}{|c|c|c|c|c|c|c|c|c|c|}
\hline DMUs & $\begin{array}{l}\text { Number of } \\
\text { doctor }\end{array}$ & $\begin{array}{c}\text { Number of } \\
\text { nurse }\end{array}$ & $\begin{array}{c}\text { Average } \\
\text { waiting } \\
\text { time }\end{array}$ & $\begin{array}{l}\text { Utilization } \\
\text { of doctor }\end{array}$ & $\begin{array}{l}\text { Utilization } \\
\text { of nurse }\end{array}$ & $\begin{array}{c}\text { Number } \\
\text { of served } \\
\text { patients }\end{array}$ & $\begin{array}{c}\text { BCC } \\
\text { efficiency } \\
\text { score }\end{array}$ & $\begin{array}{c}\text { Super } \\
\text { efficiency } \\
\text { score }\end{array}$ & $\begin{array}{l}\text { Super } \\
\text { efficiency } \\
\text { rank }\end{array}$ \\
\hline 0 & $6(2,2,2)$ & $6(2,2,2)$ & 234.07 & 96 & 100 & 96 & 1 & 1.124324 & 2 \\
\hline 1 & $6(2,2,2)$ & $7(2,2,3)$ & 235.86 & 97 & 91 & 96 & 1 & 1 & 31 \\
\hline 2 & $6(2,2,2)$ & $8(2,2,4)$ & 234.92 & 97 & 83 & 96 & 1 & 1 & 32 \\
\hline 3 & $6(2,2,2)$ & $8(2,3,2)$ & 248.52 & 99 & 94 & 97 & 1 & 1.010321 & 13 \\
\hline 4 & $6(2,2,2)$ & $8(2,3,3)$ & 251.6 & 99 & 83 & 96 & 1 & 1 & 33 \\
\hline 5 & $6(2,2,2)$ & $9(2,3,4)$ & 251.72 & 99 & 75 & 96 & 1 & 1 & 34 \\
\hline 6 & $6(2,2,2)$ & $8(2,4,2)$ & 250.38 & 99 & 88 & 98 & 1 & 1 & 35 \\
\hline 7 & $6(2,2,2)$ & $9(2,4,3)$ & 252.77 & 99 & 77 & 99 & 1 & 1 & 36 \\
\hline 8 & $6(2,2,2)$ & $10(2,4,4)$ & 252.82 & 99 & 70 & 99 & 1 & 1 & 37 \\
\hline 9 & $6(2,2,2)$ & $7(3,2,2)$ & 241.23 & 98 & 93 & 98 & 1 & 1.001509 & 29 \\
\hline 10 & $6(2,2,2)$ & $8(3,2,3)$ & 245.21 & 100 & 84 & 99 & 1 & 1.010101 & 15 \\
\hline 11 & $6(2,2,2)$ & $9(3,2,4)$ & 246.47 & 100 & 76 & 99 & 1 & 1 & 38 \\
\hline 12 & $6(2,2,2)$ & $8(3,3,2)$ & 262.57 & 77 & 86 & 100 & 1 & 1 & 39 \\
\hline 13 & $6(2,2,2)$ & $9(3,3,3)$ & 265.08 & 100 & 75 & 99 & 1 & 1 & 40 \\
\hline 14 & $6(2,2,2)$ & $10(3,3,4)$ & 265.21 & 100 & 67 & 100 & 1 & 1 & 41 \\
\hline 15 & $6(2,2,2)$ & $9(3,4,2)$ & 262.38 & 100 & 80 & 100 & 1 & 1 & 42 \\
\hline 16 & $6(2,2,2)$ & $10(3,4,3)$ & 265.95 & 100 & 70 & 100 & 1 & 1 & 43 \\
\hline 17 & $6(2,2,2)$ & $11(3,4,4)$ & 265.58 & 100 & 62 & 100 & 1 & 1 & 44 \\
\hline 18 & $6(2,2,2)$ & $8(4,2,2)$ & 241.53 & 98 & 88 & 97 & 1 & 1 & 45 \\
\hline 19 & $6(2,2,2)$ & $9(4,2,3)$ & 244.52 & 99 & 80 & 98 & 1 & 1 & 46 \\
\hline 20 & $6(2,2,2)$ & $10(4,2,4)$ & 243.28 & 100 & 71 & 97 & 1 & 1 & 47 \\
\hline 21 & $6(2,2,2)$ & $9(4,3,2)$ & 260.58 & 100 & 81 & 98 & 1 & 1 & 48 \\
\hline 22 & $6(2,2,2)$ & $10(4,3,3)$ & 263.98 & 100 & 70 & 100 & 1 & 1 & 49 \\
\hline 23 & $6(2,2,2)$ & $11(4,3,4)$ & 263.84 & 100 & 62 & 99 & 1 & 1 & 50 \\
\hline 24 & $6(2,2,2)$ & $10(4,4,2)$ & 257.84 & 100 & 75 & 101 & 1 & 1 & 51 \\
\hline 25 & $6(2,2,2)$ & $11(4,4,3)$ & 260.54 & 100 & 64 & 100 & 1 & 1 & 51 \\
\hline 26 & $6(2,2,2)$ & $12(4,4,4)$ & 261.02 & 100 & 57 & 99 & 1 & 1 & 53 \\
\hline 27 & $6(2,2,3)$ & $6(2,2,2)$ & 239 & 81 & 100 & 94 & 1 & 1 & 54 \\
\hline 28 & $6(2,2,3)$ & $7(2,2,3)$ & 182.74 & 92 & 100 & 109 & 1 & 1.080801 & 3 \\
\hline 29 & $6(2,2,3)$ & $8(2,2,4)$ & 206.18 & 97 & 94 & 114 & 1 & 1.015978 & 12 \\
\hline 30 & $6(2,2,3)$ & $7(2,3,2)$ & 248.13 & 84 & 94 & 95 & 1 & 1 & 55 \\
\hline 31 & $6(2,2,3)$ & $8(2,3,3)$ & 203.82 & 94 & 93 & 110 & 1 & 1 & 56 \\
\hline 32 & $6(2,2,3)$ & $9(2,3,4)$ & 214.65 & 98 & 85 & 117 & 1 & 1.008621 & 17 \\
\hline 33 & $6(2,2,3)$ & $8(2,4,2)$ & 249.65 & 85 & 89 & 98 & 1 & 1 & 57 \\
\hline 34 & $6(2,2,3)$ & $9(2,4,3)$ & 202.38 & 95 & 87 & 112 & 1 & 1 & 58 \\
\hline 35 & $6(2,2,3)$ & $10(2,4,4)$ & 214.13 & 99 & 80 & 117 & 1 & 1.004998 & 21 \\
\hline 36 & $6(2,2,3)$ & $7(3,2,2)$ & 248.61 & 84 & 93 & 96 & 1 & 1 & 59 \\
\hline 37 & $6(2,2,3)$ & $8(3,2,3)$ & 190.59 & 94 & 93 & 110 & 1 & 1.000486 & 30 \\
\hline 38 & $6(2,2,3)$ & $9(3,2,4)$ & 213.66 & 99 & 86 & 115 & 1 & 1.007434 & 18 \\
\hline 39 & $6(2,2,3)$ & $8(3,3,2)$ & 262.45 & 86 & 86 & 100 & 1 & 1 & 60 \\
\hline 40 & $6(2,2,3)$ & $9(3,3,3)$ & 211.4 & 96 & 85 & 112 & 1 & 1 & 61 \\
\hline 41 & $6(2,2,3)$ & $10(3,3,4)$ & 223 & 99 & 77 & 118 & 1 & 1.005682 & 20 \\
\hline 42 & $6(2,2,3)$ & $9(3,4,2)$ & 262.02 & 86 & 81 & 99 & 1 & 1 & 62 \\
\hline 43 & $6(2,2,3)$ & $10(3,4,3)$ & 215.13 & 96 & 79 & 113 & 1 & 1 & 63 \\
\hline 44 & $6(2,2,3)$ & $11(3,4,4)$ & 226.89 & 99 & 72 & 117 & 1 & 1 & 64 \\
\hline 45 & $6(2,2,3)$ & $8(4,2,2)$ & 247.72 & 84 & 88 & 95 & 1 & 1 & 65 \\
\hline
\end{tabular}


Continue TABLE 2.

\begin{tabular}{|c|c|c|c|c|c|c|c|c|c|}
\hline DMUs & $\begin{array}{c}\text { Number of } \\
\text { doctor }\end{array}$ & $\begin{array}{c}\text { Number of } \\
\text { nurse }\end{array}$ & $\begin{array}{c}\text { Average } \\
\text { waiting } \\
\text { time }\end{array}$ & $\begin{array}{l}\text { Utilization } \\
\text { of doctor }\end{array}$ & $\begin{array}{l}\text { Utilization } \\
\text { of nurse }\end{array}$ & $\begin{array}{c}\text { Number } \\
\text { of served } \\
\text { patients }\end{array}$ & $\begin{array}{c}\text { BCC } \\
\text { efficiency } \\
\text { score }\end{array}$ & $\begin{array}{c}\text { Super } \\
\text { efficiency } \\
\text { score }\end{array}$ & $\begin{array}{c}\text { Super } \\
\text { efficiency } \\
\text { rank }\end{array}$ \\
\hline 46 & $6(2,2,3)$ & $9(4,2,3)$ & 188.94 & 94 & 88 & 108 & 1 & 1.003361 & 24 \\
\hline 47 & $6(2,2,3)$ & $10(4,2,4)$ & 212.74 & 99 & 82 & 115 & 1 & 1.001763 & 28 \\
\hline 48 & $6(2,2,3)$ & $9(4,3,2)$ & 259.52 & 87 & 81 & 99 & 1 & 1 & 66 \\
\hline 49 & $6(2,2,3)$ & $10(4,3,3)$ & 209.67 & 96 & 80 & 111 & 1 & 1 & 67 \\
\hline 50 & $6(2,2,3)$ & $11(4,3,4)$ & 223.49 & 100 & 73 & 117 & 1 & 1.003028 & 26 \\
\hline 51 & $6(2,2,3)$ & $10(4,4,2)$ & 256.93 & 86 & 76 & 99 & 1 & 1 & 68 \\
\hline 52 & $6(2,2,3)$ & $11(4,4,3)$ & 208.13 & 96 & 75 & 112 & 1 & 1 & 69 \\
\hline 53 & $6(2,2,3)$ & $12(4,4,4)$ & 220.32 & 100 & 67 & 118 & 1 & 1.00611 & 19 \\
\hline 54 & $8(2,2,4)$ & $6(2,2,2)$ & 239.45 & 75 & 93 & 94 & 1 & 1 & 70 \\
\hline 55 & $8(2,2,4)$ & $7(2,23)$ & 199.02 & 83 & 100 & 110 & 0.9306952 & - & - \\
\hline 56 & $8(2,2,4)$ & $8(2,2,4)$ & 155.19 & 89 & 96 & 121 & 0.9509339 & - & - \\
\hline 57 & $8(2,2,4)$ & $7(2,3,2)$ & 248.69 & 78 & 94 & 95 & 0.8571429 & - & - \\
\hline 58 & $8(2,2,4)$ & $8(2,3,3)$ & 205.04 & 85 & 94 & 111 & 0.8407035 & - & - \\
\hline 59 & $8(2,2,4)$ & $9(2,3,4)$ & 168.72 & 91 & 89 & 121 & 0.9024135 & - & - \\
\hline 60 & $8(2,2,4)$ & $8(2,4,2)$ & 248.7 & 79 & 90 & 98 & 0.7975498 & - & - \\
\hline 61 & $8(2,2,4)$ & $9(2,4,3)$ & 201.89 & 86 & 88 & 113 & 0.8170120 & - & - \\
\hline 62 & $8(2,2,4)$ & $10(2,4,4)$ & 171.31 & 90 & 82 & 121 & 0.8838350 & - & - \\
\hline 63 & $8(2,2,4)$ & $7(3,2,2)$ & 249.04 & 77 & 93 & 96 & 0.8571429 & - & - \\
\hline . & . & . & . & . & . & . & . & . & . \\
\hline . & . & . & . & . & . & . & . & . & . \\
\hline 700 & $11(4,4,3)$ & $11(4,4,3)$ & 21.42 & 67 & 74 & 122 & 1 & 1.038404 & 8 \\
\hline 701 & $11(4,4,3)$ & $12(4,4,4)$ & 22.19 & 67 & 68 & 122 & 0.9939408 & - & - \\
\hline 702 & $12(4,4,4)$ & $6(2,2,2)$ & 254.57 & 48 & 100 & 94 & 1 & 1 & 71 \\
\hline 703 & $12(4,4,4)$ & $7(2,2,3)$ & 213.04 & 56 & 100 & 109 & 0.9045769 & - & - \\
\hline 704 & $12(4,4,4)$ & $8(2,2,4)$ & 170.32 & 63 & 97 & 120 & 0.8185152 & - & - \\
\hline 705 & $12(4,4,4)$ & $7(2,3,2)$ & 186.28 & 54 & 100 & 105 & 0.9284910 & - & - \\
\hline 706 & $12(4,4,4)$ & $8(2,3,3)$ & 147.87 & 61 & 97 & 118 & 0.836050 & - & - \\
\hline 707 & $12(4,4,4)$ & $9(2,3,4)$ & 123.57 & 63 & 90 & 122 & 0.7560224 & - & - \\
\hline 708 & $12(4,4,4)$ & $8(2,4,2)$ & 109.76 & 60 & 99 & 116 & 0.8900785 & - & - \\
\hline 709 & $12(4,4,4)$ & $9(2,4,3)$ & 86.83 & 63 & 91 & 122 & 0.7986992 & - & - \\
\hline 710 & $12(4,4,4)$ & $10(2,4,4)$ & 73.78 & 63 & 83 & 122 & 0.7804462 & - & - \\
\hline 711 & $12(4,4,4)$ & $7(3,2,2)$ & 175.89 & 53 & 99 & 102 & 0.9288469 & - & - \\
\hline 712 & $12(4,4,4)$ & $8(3,2,3)$ & 135.87 & 61 & 97 & 117 & 0.8466308 & - & - \\
\hline 713 & $12(4,4,4)$ & $9(3,2,4)$ & 109.44 & 63 & 90 & 122 & 0.766572 & - & - \\
\hline 714 & $12(4,4,4)$ & $8(3,3,2)$ & 115.03 & 58 & 98 & 113 & 0.8757709 & - & - \\
\hline 715 & $12(4,4,4)$ & $9(3,3,3)$ & 87.02 & 63 & 90 & 122 & 0.7893400 & - & - \\
\hline 716 & $12(4,4,4)$ & $10(3,3,4)$ & 72.84 & 63 & 82 & 122 & 0.782108 & - & - \\
\hline 717 & $12(4,4,4)$ & $9(3,4,2)$ & 58.29 & 62 & 91 & 121 & 0.9192431 & - & - \\
\hline 718 & $12(4,4,4)$ & $10(3,4,3)$ & 43.9 & 62 & 81 & 122 & 0.8945416 & - & - \\
\hline 719 & $12(4,4,4)$ & $11(3,4,4)$ & 37.57 & 62 & 74 & 122 & 0.8784530 & - & - \\
\hline 720 & $12(4,4,4)$ & $8(4,2,2)$ & 130.51 & 56 & 96 & 108 & 0.8429559 & - & - \\
\hline 721 & $12(4,4,4)$ & $9(4,2,3)$ & 97.43 & 63 & 92 & 121 & 0.7851720 & - & - \\
\hline 722 & $12(4,4,4)$ & $10(4,2,4)$ & 78.58 & 63 & 83 & 122 & 0.7720697 & - & - \\
\hline 723 & $12(4,4,4)$ & $9(4,3,2)$ & 72.78 & 61 & 94 & 118 & 0.8726331 & - & - \\
\hline 724 & $12(4,4,4)$ & $10(4,3,3)$ & 54.01 & 63 & 83 & 122 & 0.8335607 & - & - \\
\hline 725 & $12(4,4,4)$ & $11(4,3,4)$ & 43.84 & 62 & 75 & 122 & 0.8417472 & - & - \\
\hline 726 & $12(4,4,4)$ & $10(4,4,2)$ & 33.74 & 62 & 83 & 121 & 0.9684062 & - & - \\
\hline 727 & $12(4,4,4)$ & $11(4,4,3)$ & 22.73 & 62 & 73 & 122 & 0.9887014 & - & - \\
\hline 728 & $12(4,4,4)$ & $12(4,4,4)$ & 17.78 & 62 & 68 & 122 & 1 & 1.204724 & 1 \\
\hline
\end{tabular}

**Note: (a/b/c) is (morning shift/evening shift/night shift) 
TABLE 3. Comparison of $\mathrm{DMU}_{0}$ (Current) and DMU63 for weekdays, and $\mathrm{DMU}_{0}$ and DMU728 for weekends and public holidays

\begin{tabular}{lcccc}
\hline \multirow{2}{*}{ Items } & \multicolumn{2}{c}{ Weekdays } & \multicolumn{2}{c}{ Weekends } \\
\cline { 2 - 5 } & $\mathrm{DMU}_{0}($ Current $)$ & DMU63 & DMU $_{0}($ Current $)$ & DMU728 \\
\hline Number of doctor & $6(2,2,2)$ & $9(3,3,3)$ & $6(2,2,2)$ & $12(4,4,4)$ \\
Number of nurse & $6(2,2,2)$ & $9(3,3,3)$ & $6(2,2,2)$ & $12(4,4,4)$ \\
Average waiting time (min) & 78.75 & 12.80 & 234.07 & 17.78 \\
Average utilization of doctor (\%) & 85 & 59 & 96 & 62 \\
Average utilization of nurse (\%) & 95 & 65 & 100 & 68 \\
Number of served patients & 76 & 79 & 96 & 122 \\
\hline
\end{tabular}

**Note: $(\mathrm{a} / \mathrm{b} / \mathrm{c})$ is (morning shift/evening shift/night shift)

patients' waiting time for the current scenarios records at 78.75 min which fulfils the KPIs set for the Green Zone.

Besides that, from the improvements of both groups, the optimal utilization results are closer to good utilization of resources in service sector which is around $70 \%$ and $80 \%$. Henceforth, the proposed new schedule for doctors and nurses during weekdays, weekends and public holidays enables the reduction of average patients' waiting time, helps achieve the department's KPI, reduce high utilization of doctors and nurses as well as increases the number of patients' being served. Furthermore, this permits the optimum utilization of consultation rooms as compared to the current usage where only two rooms out of five rooms are being utilized.

\section{CONCLUSION}

Conclusively, EDHUSM's Green Zone is rather hectic on weekends and public holidays as compared to weekdays. The proposed alternatives resources allocations have not only demonstrated the potential benefits for the weekends and public holidays, but is also providing in the event the management requires better result and improvement for the weekdays. The management can choose the best schedule of doctors and nurses suggested to provide better quality of services for their patients. Among the future plans for this research is to forecast and guide the management for their long-term plans of EDHUSM's Green Zone by using System Dynamics Simulation method.

\section{ACKNOWLEDGEMENTS}

The author would like to thank the Emergency Department of Hospital Universiti Sains Malaysia (HUSM) for granting permission to conduct this study.

\section{REFERENCES}

Al-Refaie, A., Fouad, R.H. \& Mohammad, S. 2014. Applying simulation and DEA to improve performance of emergency department in a Jordanian Hospital. Journal of Simulation Modelling and Theory 41: 58-72.

Al-Shayea, A.M. 2011. Measuring hospital's unit's efficiency: A data envelopment analysis approach. International Journal of Engineering \& Technology IJET-IJENS 11(6): 44-53.
Banker, R., Charnes, A. \& Cooper, W. 1984. Some models for estimating technical and scale efficiencies in data envelopment analysis. Management Science 30(9): 10781092.

Blasak, E.R., Starks, W.D., Armel, S.W.\& Hayduk, C. 2003. The use of simulation to evaluate hospital operations between the emergency department and a medical telemetry unit. Proceeding of 2003 Winter Simulation Conference. pp. 1887-1893.

Brailsford, S.C., Desai, S.M. \& Viana, J. 2010. Towards the holygrail: Combining system dynamics and discrete-event simulation in healthcare. Proceeding of 2010 Winter Simulation Conference. pp. 2293-2303.

Chahal, K. \& Eldabi, T. 2008. Applicability of hybrid simulation to different models of governance in UK healthcare. Proceeding of 2008 Winter Simulation Conference. pp. 1469-1477.

Chahal, K. \& Eldabi, T. 2010. A generic framework for hybrid simulation in healthcare. Proceeding of the 28th International Conference of the System Dynamics Society. pp. 526-541.

Chun, Y.L. \& Okudan, G.E. 2009. An exploration on the use of data envelopment analysis for product line selection. Industrial Engineering and Management Systems 8(1): 47-53.

Cooper, W.W., Lawrence, M.S. \& Kaoru, T. 2007. Data Envelopment Analysis. 2nd ed. New York: Springer.

Eduardo, C., Manel, T., Francisco, E. \& Ma, L.I. 2012. ABMS optimization for emergency department. Proceedings of 2012 Winter Simulation Conference. pp. 1039-1042.

Ertay, T., Ruan, D. \& Tuzkayu, U.R. 2006. Integrating data envelopment analysis and analytic hierarchy for the facility layout design in manufacturing systems. Information Sciences 176: 237-262.

Gunal, M.M. \& Pidd, M. 2010. Discrete event simulation for performance modelling in healthcare: A review of the literature. Journal of Simulation 4(1): 42-51.

Kelton, W.D., Sadowski, R.P. \& Zupick, N.B. 2015. Simulation with Arena. 6th ed. Singapore: McGraw-Hill Education.

Komashie, A. \& Mousavi, A. 2005. Modeling emergency departments using discrete event simulation techniques. Proceedings of 2005 Winter Simulation Conference. pp. 2681-2685.

Mohd, R.Z., Muthukkaruppan, Kassim, I. \& Rashidi, A. 2016. Estimating the right allocation of doctors in emergency department. Proceedings of 2016 Management International Conference (KMICe). pp. 446-452.

Norazura, A., Noraida, A.G., Anton, A.K. \& Razman, M.T. 2014. Managing resource capacity using hybrid simulation. 
International Conference on Quantitative Sciences and Its Applications. pp. 504-511.

Norazura, A., Noraida,A.G.,Anton,A.K.\& Razman, M.T. 2012. Evaluating emergency department resource capacity using simulation. Modern Applied Science 6(11): 9-19.

Ruzanita, M.R., Wan, R.I. \& Izzaamirah, I. 2014 . An integrated simulation and data envelopment analysis in improving SME food production system. World Journal of Modelling and Simulation 10(2): 136-147.

Seiford, L. \& Zhu, J. 1999. Infeasibility of super-efficiency data envelopment analysis models. INFOR 37(2): 174-186.

Wan, M.W.M.A., Wan, R.I. \& Husyairi, H. 2016. Estimating emergency department capacity using simulation and data envelopment analysis. Indian Journal of Science and Technology 9(28): 1-10.

Weng, S.J., Tsai, L.M., Wang, C.Y., Chang, C.Y. \& Gotcher, D. 2011. Using simulation and data envelopment analysis in optimal healthcare efficiency allocations. Proceeding of 2011 Winter Simulation Conference. pp. 1295-1305.

Nazhatul Sahima Mohd Yusoff

Faculty of Computer Sciences \& Mathematics

Universiti Teknologi MARA (UiTM) Cawangan Kelantan

18500 Machang, Kelantan Darul Naim

Malaysia
Choong-Yeun Liong* \& Wan Rosmanira Ismail School of Mathematical Sciences

Faculty of Science and Technology

Universiti Kebangsaan Malaysia 43600 UKM Bangi, Selangor Darul Ehsan Malaysia

Abu Yazid Md Noh

Emergency Department

Hospital Universiti Sains Malaysia (HUSM)

Jalan Raja Perempuan Zainab 2

16150 Kota Bharu, Kelantan Darul Naim

Malaysia

*Corresponding author; email: lg@ukm.edu.my

Received: 18 September 2017

Accepted: 19 July 2018 